\title{
Meiotic Analysis in Wild Diploid Arachis Species
}

\author{
G. I. Lavia ${ }^{1,2, *}$, A. Fernández ${ }^{1,3}$, C. E. Simpson ${ }^{4}$ and G. Seijo ${ }^{1}$ \\ ${ }^{1}$ Instituto de Botánica del Nordeste (UNNE-CONICET), \\ C.C. 209, 3400 Corrientes, Argentina \\ ${ }^{2}$ Facultad de Ciencias Agrarias, Universidad Nacional del Nordeste, \\ Sgto. Cabral 2131, 3400 Corrientes, Argentina \\ ${ }^{3}$ Facultad de Ciencias Exactas y Naturales y Agrimensura, Universidad Nacional del Nordeste, \\ Campus Libertad, 3400 Corrientes, Argentina \\ ${ }^{4}$ Texas Agricultural Experiment Station, Texas A \& M University, \\ Stphenville, Texas 76401, USA \\ Accepted July 17, 2001
}

\begin{abstract}
Summary Meiotic behaviour of $A$. lignosa, A. rigonii (Sect. Procumbentes), A. microsperma, $A$. simpsonii and A. williamsii (Sect. Arachis) is reported for the first time, and for A. batizocoi, A. stenosperma and $A$. villosa were studied in different accessions than the previously reported ones. All the species analyzed were diploid forming $10 \mathrm{II}$ at diakinesis-metaphase I, except $A$. stenosperma which presented $8 \mathrm{II}+1 \mathrm{IV}$ in $3 \%$ of the pollen mother cells. Most of the bivalents were of the ring type, and only 1 or 2 bivalents were usually of the rod type. Chiasmata were always located in distal to terminal position even at diplotene and diakinesis. Normal segregation of bivalents was observed which is in accordance with the recorded high pollen stainability. Only 1 pair of chromosomes was easily recognized, that being the very small "A" pair in the A genome of Arachis section species. This small pair can be used also at meiosis to distinguish the A and B genomes.
\end{abstract}

Key words Arachis, Meiosis, A and B genomes.

The genus Arachis (Leguminosae) is an indigenous genus of South America, and consists of about 80 species. Krapovickas and Gregory (1994) have recognized 9 sections based in morphological characters, cross compatibility and fertility of the hybrids. The tetraploid cultigen $A$. hypogaea $(2 n=40)$ is the most important species of the genus and it belongs to section Arachis. In this section, there is another tetraploid species, A. monticola, and more than 30 diploid species. All these species are being used as sources of variability for genetic improvement of the cultivated peanut. Many diploid species were found to be resistant to the primary diseases and pests of $A$. hypogaea and are being tested in crosses for introduction of resistance genes. Species of other sections have also been tested in crossing programs, however it was reported that hybrids are rarely produced.

To use this potential source of germplasm efficiently, an understanding of the meiotic behaviour of the chromosomes of diploid species is necessary and constitutes the first step in the knowledge of the genomics of a genus. However, very few (less than 17\%) species of Arachis have been studied meiotically, and this kind of information is still lacking for several sections. In this sense, the present study was undertaken to describe comparatively the meiotic behaviour of 10 wild diploid species of Arachis that are cultivated at the Texas Agricultural Experiment Station, USA (TAES) and Instituto de Botánica del Nordeste, Argentina (IBONE) with the hope to provide valuable information for the genetic improving programs.

Materials and methods

The analyzed material was collected from plants growing under greenhouse conditions at

* Corresponding author, e-mail: glavia@arnct.com.ar 
TAES and from plants growing in the experimental field of IBONE. Vouchers of original collections are kept at IBONE (CTES). The localities of collection and collectors are shown in Table 1.

Meiotic study was performed on inflorescences fixed in ethanol:lactic acid 5:1 for $24 \mathrm{~h}$ (Fernández 1973) and then transferred to $70 \%$ ethanol and kept refrigerated until used. Floral buds of appropriate size were removed from the inflorescence, and each of its anthers was dissected individually. They were cut transversally and the content of pollen sacs extracted on a drop of $3 \%$ acetic orcein by pressing the anther halves, while the remainder was discarded. After placing the cover slip, the slide was warmed over an alcohol lamp to improve the staining contrasts between the chromosomes and the cytoplasm. Representative permanent slides were made using Euparal as mounting medium. Photomicrographs were taken on a Zeiss microscope using Kodalith film. Pollen viability was estimated by the acetocarmine-glycerin technique. For each species 500 pollen grains were scored, considering viable grains with uniformly dark stained cytoplasm.

Table 1. Studied material

\begin{tabular}{ll}
\hline \hline \multicolumn{1}{c}{ Species } & \multicolumn{1}{c}{ Collectors and procedence } \\
\hline $\begin{array}{l}\text { Section Procumbentes } \\
\text { A. lignosa } \text { (Chodat et Hassl.) Krapov. et W. C. Gregory }\end{array}$ & KCAh 14248, PARAGUAY, Concepción, Concepción \\
$\begin{array}{l}\text { A. rigonii Krapov. et W. C. Gregory } \\
\text { Section Arachis }\end{array}$ & GKP 10034, BOLIVIA, Santa Cruz, Santa Cruz de la Sierra \\
$\begin{array}{l}\text { A. batizocoi Krapov. et W. C. Gregory } \\
\text { A. cardenasii Krapov. et W. C. Gregory }\end{array}$ & K 9505, BOLIVIA, Santa Cruz, Cordillera, Parapetí \\
& GKP 10017, BOLIVIA, Santa Cruz, Chiquitos, Roboré \\
& KSSc 36015, BOLIVIA, Santa Cruz, Chiquitos, 2 km SW \\
A. microsperma Krapov., W. C. Gregory et Valls & Ve Roboré \\
$\begin{array}{l}\text { A. simpsonii Krapov. et W. C. Gregory } \\
\text { A. stenosperma Krapov. et W. C. Gregory }\end{array}$ & VSPmSv 13732, BRASIL, MT, Porto Esperidão \\
A. villosa Benth. & VSSaGdW 7762, BRASIL, MT, Barra do Garças \\
A. williamsii Krapov. et W. C. Gregory & HLKOj 357, ARGENTINA, Corrientes, Paso de los Libres \\
\hline
\end{tabular}

Collectors: $\mathrm{Ah}=\mathrm{L}$. Z. Ahumada, $\mathrm{Aj}=\mathrm{M}$. Araujo, C=C. L. Cristobal, $\mathrm{Cl}=\mathrm{D}$. Claure, $\mathrm{G}=\mathrm{W}$. C. Gregory, Gd=I. J. Godoy, $\mathrm{H}=\mathrm{R}$. O. Hammons, $\mathrm{J}=\mathrm{L}$. Jank, $\mathrm{K}=\mathrm{A}$. Krapovickas, L=W. R. Landford, $\mathrm{Oj}=\mathrm{H}$. R. Ojeda, P=J. R. Pietrarelli, $\mathrm{Pe}=$ M. I. Penteado, $\mathrm{Po}=$ A. Pott, $\mathrm{Pm}=$ R. N. Pittman, $\mathrm{S}=$ C. E. Simpson, $\mathrm{Sa}=$ H. T. Stalker, $\mathrm{Sc}=$ A. Schinini, $\mathrm{Sv}=\mathrm{G} . \mathrm{P} . \mathrm{Silva}$, V. $=$ J. F. M. Valls, W=W. L. Werneck, Wi=D. E. Williams.

Table 2. Chromosome associations and pollen stainability

\begin{tabular}{lcccc}
\hline \multicolumn{1}{c}{ Species } & Cells & \multicolumn{2}{c}{ Meiotic associations } & Pollen stainability \\
& & Il \% & IV \% & \% \\
& 25 & 100 & - & 96.43 \\
A. lignosa & 30 & 100 & - & 98.80 \\
A. rigonii & 10 & 100 & - & 98.10 \\
A. batizocoi & 10 & 100 & - & 99.60 \\
A. cardenasii 10017 & 39 & 100 & - & 100 \\
A. microsperma & 36015 & 100 & - & 97.50 \\
A. simpsonii & 30 & 100 & - & 98.00 \\
A. stenosperma & 25 & 97 & - & 98.17 \\
A. villosa & 25 & 100 & & 99.80 \\
A. williamsii & 30 & 100 & & \\
\hline
\end{tabular}




\section{Results and discussion}

All the species analyzed were diploid with $10 \mathrm{II}$ at diakinesis-metaphase I, except $A$. stenosper$m a$ which presented 8 II +1 IV (Fig. 1e) in $3 \%$ of the pollen mother cells. Meiotic behaviour of $A$. lignosa (Fig. 1a), A. rigonii (Fig. 1b), A. williamsii (Fig. 1d), A. microsperma and A. simpsonii (Fig. 1f) is reported for the first time. For the other studied species, there are antecedents in $A$. villosa (Smartt 1964, Stalker and Wynne 1979, Singh and Moss 1982), A. batizocoi (Fig. 1c), A. stenosperma (Smartt et al. 1978, Stalker and Wynne 1979, Singh and Moss 1982) and A. cardenassii (Fig. 1g) (Smartt 1964, Resslar and Gregory 1979, Singh and Moss 1982). No difference in meiotic behaviour was detected between accessions.

All the studied species presented a regular meiotic behaviour. At metaphase I most of the bivalents were of the ring type, and only 1 or 2 bivalents per pollen mother cell were usually of the rod type. Chiasmata were always located in distal to terminal position even at diplotene and diakinesis. Segregation of bivalents was normal and no bridges or laggard chromosomes were observed. This regularity in meiotic behaviour is in accordance with the high pollen stainability. The slight reduction of viability of 1 or $2 \%$ observed in most of the species was due to non-colored pollen grains and neither micrograin nor macrograin were observed.

The chromosome numbers observed in the analyzed species are in accordance with the previously reported ones, mainly from somatic chromosomes analysis. In section Arachis 2 basic chromosome numbers have been reported, $x=10$ and $x=9$ (Lavia 1996, 1998), however all the species studied here belong to the group of $x=10$, which is by far the most widespread number among the species of the genus.

At diplotene and diakinesis in A. cardenasii, A. microsperma, A. simpsonii, A. stenosperma and $A$. villosa one small bivalent is clearly distinguished. This small bivalent is usually of the rod type with a small pericentromeric region of condensed chromatin, but with distal region diffuse and poorly stained. This behaviour was also observed in somatic mitosis (Fernández and Krapovickas 1994, Lavia 1996). This chromosome is the small pair exclusive of section Arachis, which was termed by Husted (1933) as "A" chromosomes. On the other hand, in A. lignosa and A. rigonii (Sect. Procumbentes), A. williamsii (Sect. Arachis) there is no chromosome that resembles the features of the bivalent formed by "A" chromosomes.

The tetravalent observed in $A$. stenosperma probably arose as a consequence of a reciprocal interchange in heterozygosity. Probably, in the tetravalent participate the "A" chromosomes, because these chromosomes were not distinguished among the bivalents (Fig. 1e). Lavia (1999) studied the karyotype of this accession, and no heteromorphic chromosome pair was detected. Moreover, no heteromorphic bivalent was observed, therefore the interchange might have been of equal size (Darlington 1965). The low frequency of tetravalent formation suggests that this translocation may be of small size. Tetravalents were also observed in the diploids $A$. villosa and A.duranensis with a frequency of 4 and 5\% respectively (Singh and Moss 1982). These authors attributed tetravalent formation to the existence of reciprocal translocation interchanges. The presence of translocations in diploid wild species suggests that these structural changes may be a mechanism of karyotype differentiation, which can lead to speciation.

In the prophase of $A$. microsperma chromatin passage from one pollen mother cell to another was observed, though in low frequency (Fig. 1h). This phenomenon was termed cytomixis by Gates (1911) and was reported to occur in several species of diverse families. Several hypothesis have been postulated to explain its origin, ranging from technique artifacts (Johansen 1940) environmental factors (Morisset 1978, Narain 1979) to genetic imbalance in hybrid types (Gottschalk 1970, Nirmala and Kaul 1994). In this study it was not possible to associate the occurrence of cytomixis to any of these factors, however the ones referred to genetic imbalance can be discarded, because all the analyzed species are wild diploids. Also, considering the pollen stainability, it seems that cy- 

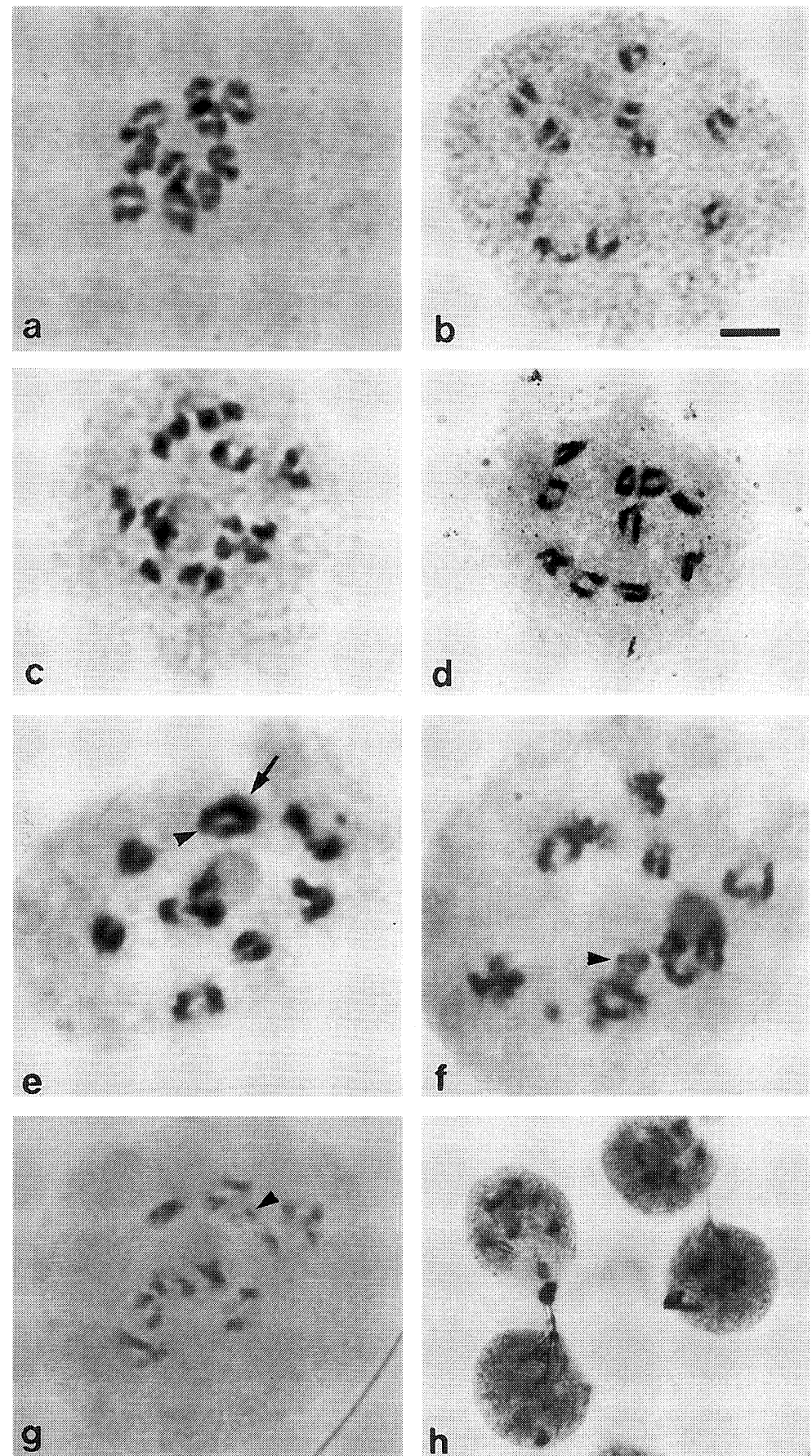

Fig. 1. Meiotic chromosomes. a) A. lignosa, b) A. rigonii, c) A. batizocoi, d) A. williamsii, e) A. stenosperma, the "A" chromosomes integrate the tetravalent, f) A. simpsonii, g) A. cardenasii, h) A. microsperma, cytomixis in prophase. Arrowheads show the "A" chromosomes and arrow in e shows the tetravalent. In $\mathrm{a}-\mathrm{g}$ bar $=5 \mu \mathrm{m}$ and in $\mathrm{h}$ bar $=16 \mu \mathrm{m}$. 
tomixis does not have a great effect on the fertility of these species as was reported for some other legume species (Seijo 1996).

Based on A chromosomes Smartt et al. (1978) proposed the existence of 2 genomic formula, the ones with A chromosomes, genome A, and the ones without it, genome B. Both of them are in the tetraploid peanut, however the cross compatibility between diploid species with the cultivated one is very variable. Stalker et al. (1991) have proposed the generalized existence of A genome within section Arachis, while A. batizocoi being the only species with the B genome and A. glandulifera with $\mathrm{D}$ genome. Moreover, for $A$. valida and A. matiensis these authors suggested additional formulae.

The meiotic analysis of the present report shows that 2 groups of species can be distinguished, the ones with A chromosomes and the ones without them. Each group may be attributed respectively to the A and B genomes proposed by Smartt et al. (1978). Therefore, differences in crossability and hybrid production between wild diploids and the cultivated peanut may be mainly due to genetic differentiation rather than chromosome change. However, the presence of reciprocal interchanges suggest that at least some structural changes may participate in species diversification, and cryptic changes can not be ruled out, even though, they are difficult to observe due to the small size of Arachis chromosomes.

\section{Acknowledgements}

The authors wishes to acknowledge the financial support to SECYT de la Universidad Nacional del Nordeste, Consejo Nacional de Investigaciones Científicas y Técnicas and IICA.

\section{References}

Darlington, C. D. 1965. Recent Advances in Cytology. J. \& A. Churchill LTD., London.

Fernández, A. 1973. El ácido láctico como fijador cromosómico. Bol. Soc. Arg. Bot. 15: 287-290.

— and Krapovickas, A. 1994. Cromosomas y evolución en Arachis (Leguminosae). Bonplandia 8: 187-220.

Gates, R. R. 1911. Pollen formation in Oenothera gigas. Ann. Bot. 25: 909-940.

Gottschalk, W. 1970. Chromosome and nucleus migration during microsporogenesis of Pisum sativum. Nucleus 13: 1-9.

Husted, L. 1933. Cytological studies on the peanut, Arachis I. Chromosome number and morphology. Cytologia 5: 109-117.

Johansen, D. A. 1940. Plant Microtechnique. McGraw Hill, New York.

Krapovickas, A. and Gregory, W. C. 1994. Taxonomía del género Arachis (Leguminosae). Bonplandia 8: 1-186.

Lavia, G. I. 1996. Estudios cromosómicos en Arachis (Leguminosae). Bonplandia 9: 111-120.

- 1998. Karyotypes of Arachis palustris and A. praecox (section Arachis), two species with basic chromosome number $x=9$. Cytologia 63: $177-181$.

- 1999. Caracterización cromosómica del germoplasma de maní. Tesis Doctoral. Universidad Nacional de Córdoba, Córdoba, Argentina.

Morisset, P. 1978. Cytomixis in pollen mother cells of Ononis (Leguminosae). Can. J. Genet. Cytol. 20: 243-252.

Narain, P. 1979. Cytomixis in the pollen mother cells of Hemerocallis Linn. Curr. Sci. 48: 996-998.

Nirmala, C. and Koul, M. 1994. Male sterility in pea IV. Cytologia 59: 195-201.

Resslar, P. M. and Gregory, W. C. 1979. A cytological study of three diploid species of the genus Arachis L. J. Heredity 70: 13-16.

Seijo, G. 1996. Spontaneous cytomixis in the microsporogenesis of Sweet pea Lathyrus odoratus (Leguminosae). Cytologia 61: 189-195.

Singh, A. K. and Moss, J. P. 1982. Utilization of wild relative in genetic improvement of Arachis hypogaea L. Theor. Appl. Genet. 61: 305-314.

Smartt, J. 1964. Cross-compatibility relationship between the cultivated peanut Arachis hypogaea L. and other species of the genus Arachis. Ph.D. thesis, North Carolina State University, Raleigh.

-, Gregory, W. C. and Gregory, M. P. 1978. The genomes of Arachis hypogaea 1. Cytogenetic studies of putative genome donors. Euphytica 27: 665-675.

Stalker, H. T. and Wynne, J. C. 1979. Cytology of interspecific hybrids in section Arachis of peanuts. Peanut Science 6: 
110-114.

—, Dhesi, J. S., Parry, D. C. and Hahn, J. H. 1991. Cytological and interfertility relationships of Arachis section Arachis. Amer. J. Bot. 78: 238-246. 